$$
\begin{aligned}
& \text { SF } 258 \\
& \text { N5C6 } \\
& 1912 b
\end{aligned}
$$





\section{TREASURY DEPARTMENT}

Public Health and Marine-Hospital Service of the United States

REPRINT FROM PUBLIC HEALTH REPORTS.-No. 78

\section{REPORT OF THE COMMISSION ON MILK STANDARDS APPOINTED BY THE NEW YORK MILK COMMITTEE}

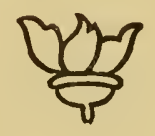




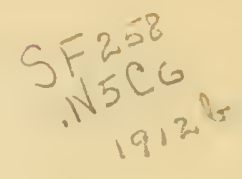

In the House of Representatives,

August 10, 1912.

Resolved, That there be printed for the use of the House document room for distribution fifty thousand copies of the "Report of the Commission on Milk Standards appointed by the New York Milk Committee," as published in the Public Health Reports, volume twenty-seren, numbered nineteen, May tent?, nineteen hundred and twelve. Attest :

South Trimble, Clerk.

(2)

D. OF D.

JAN $\| 11913$ 
REPORT OF THE COMMISSION ON MILK STANDARDS AP. POINTED BY THE NEW YORK MILK COMMITTEE. ${ }^{1}$

\title{
INTRODUCTION.
}

\author{
PERSONNEL.
}

The New York Milk Committee, which is a roluntary organization working in the interests of improving the milk supply of New York City, in March, 1911, decided to appoint a commission on milk standards. The men who have served on the commission are as follows:

Dr. IT. A. Evans, professor pleventive medicine, Northwestern University; health editor, Chicago Tribune, Chicago, Ill., chairnan.

Dr. B. I. Arms, director of bacteriological laboratory, department of healti, Boston, Mass.

Dr. John F. Anderson, director of hygienic laboratory, United States Public Health and Marine-Hospital Service, Washington, D. C.

Prof. H. W. Conn, director of bacteriological laboratory, Connerticut State Board of Health, department of biology. Wesleyan University, Middletown, Conn.

Dr. E. C. Iers, health officer, Richmond. Vir.

D1. 1. D. Melrili, Chief of Lurean of Animal Industry. United States Department of Agriculture, Washington, D. C.

Dr. William H. Park, director of laboratories, department of health of New York City, foot of East Sixteenth Street, New York City.

Mr. Raymond A. Pearson, commissioner of agriculture, Albany, N. Y.

Dr. M. P. Ravenel, director of hygienic laboratory, University of Wisconsin, Madison, Wis.

Prof. M. J. Rosenau, department of hygiene and preventive medicine, Harvard Merlical School, Boston, Mass.

Prof. Henry C. Sherman, department of chemistry, Columbia University, New York City.

Dr. A. II. Stewart, antitoxin laboratories, department of health and charities, Philadelphi: , Pa.

Dr. William Stokes, bacteriologist to State and city health departments, Baltimore, Md.

Prof. William A. Stocking, department of dairy industry, Cornell University, Ithaca, N. $\mathrm{Y}$.

Mr. Chester H. Wells, health officer, Montclair, N. J.

Dr. I. I. Var Slyke, department of chemistry, New York Agricultural Experiment Station, Genera, N. Y.

Dr. Charles E. North, consulting sanitarian, member New York Milk Committee, New York City, secretary.

\section{ORIGIN AND ORGANIZATION.}

The appointment of this commission was the direct result of the observation of the New York Milk Committee that there was great incompleteness and lack of uniformity in the milk standards, milk ordinances, and rules and regulations of public-health authorities throughout the country for the control of public-milk supplies.

${ }^{1}$ Reprint from the Public Health Reports, Vol, xxvir, No. 19, May 10, 1912. 
There was a need that health officers be furnished conclusions drawn from large experience and mature judgment and that ordinances should be as free from erroneous positions and as uniform as possible.

A special committee of the New York Milk Committee was appointed to consider names of more than 200 men of prominence in medicine, sanitation, public health, and laboratory work, particulary those recognized as authorities on the milk question. Since regulations are based on standards and standards are based chiefly on laboratory analyses, the subcommittee selected 20 names of men distinguished for their knowledge of the bacteriological and chemical examination of milk and for the enforcement of standards based on such laboratory examinations. Two of those chosen declined to serve and another resigned after the first meeting, so that there were 17 members who have taken an active part in the work of the commission.

\section{PURPOSES.}

While this commission was created by and its expenses were borne by the New York Milk Committee, it has not been the intention of that committee that the commission should have the New York City milk problem solely in mind. It was desired that the commission should make recommendations that might be adopted by any city or town in the country.

\section{MEETINGS.}

The first meeting of the commission was held in the New York Academy of Medicine on May 22, 1911. The chief work of that meeting consisted in a general discussion of the scope of the commission's purpose and the appointment of a number of standing committees to which the several divisions of the work were assigned. The subjects included bacteriological standards, chemical standards, grades and classes of milk, standard ordinances, laws, and licenses, and new questions.

The second meeting of the commission was held at the New York Academy of Medicine on October 5 and 6, 1911, at which time the reports of the standing committees were received and modified, and the major part of them tentatively adopted. Special committees were appointed at this time to consider certain specific matters which were presented and final action on all matters was deferred until the third and final meeting.

The third and last meeting of the commission was held in Homer, N. Y., on January 25, and at the New York Academy of Medicine, January 26 and 27,1912 . The commission visited Homer in order that the members might inspect the central station and the dairy farms of the New York Dairy Demonstration Co. as a means of helping them to form a correct judgment of the relative value to be given to methods and equipment in the rules and regulations that they might recommend.

The commission voted to divide its report into a preamble of explanation and a report containing its resolutions regarding milk standards and rules and regulations. 


\section{PREAMBLE.}

\section{NEED OF MILIT CONTROL.}

Proper milk standards, while they are essential to efficient milk control by public health authorities and have as their object the protection of the milk consumer, are also necessary for the ultimate well-being of the milk industry itself. Public confidence is an asset of the highest value in the milk business. The milk producer is interested in proper standards for milk, since these contribute to the control of bovine tuberculosis and other cattle diseases and distingmish between the good producer and the bad producer. The milk dealer is immediately classified by milk standards, either into a seller of first-class milk or a seller of second-class milk, and such distinction gives to the seller of first-class milk the commercial rewards which he deserves, while it inflicts just penalties on the seller of second-class milk. For milk consumers, the setting of definite standards accompanied by proper labeling makes it possible to know the character of the milk which is purchased and to distinguish good milk from bad milk. In the matter of public health administration, standards are absolutely necessary to furnish definitions around which the rules and regulations of city health departments can be drawn, and the milk supply efficiently controlled.

\section{PUBLIC HEALTII AUTHORITIES.}

While public health authorities must necessarily see that the source of supply and the chemical composition should correspond with established definitions of milk as a food, their most important dity is to prevent the transmission of disease through milk. This means the control of infantile diarrhea, typhoid fever, tuberculosis, diphtheria, scarlet fever, septic throat infections, and other infections diseases in so far as they are carried by milk.

SEPTIC SORE THLROAT.

Septic sore throat deserves special mention because of the frequency in recent years with which outbreaks of this disease have been traced to milk supplies. The suggestion has been made that the infection of the milk is due to udder infection of the cow and on the other hand it has been suggested that it is due to contact with infected persons. The uncertainty can not be dispelled until cases of septic sore throat are regularly reported and tabulated by public health authorities. The commission therefore recommends that public health authorities make septic sore throat a reportable disease.

\section{ECONOMIC PROBLEM.}

The commission recognizes the magnitude of the milk industry, and that the improvement of milk supplies is primarily an economic problem. The success achieved by the experiment in milk production, which has been carried out on a very large seale by the New York Dairy Demonstration Co., is an illustration of the fact that an extra price or premium paid to the producer for cleanliness and care will 
bring results far more quickly and certainly than instructions or official inspection. But while the basic problem is economic, and must eventually be solved by commerce, public health anthorities must show the way and must establish standards and regulations in the interest of consumers, the value of which even the consumers themselves often fail to appreciate.

IEGAL REQUIREMENTS.

A prime requisite of effectiveness is that local milk laws shall not exceed sanitary limitations. The commission has not entered into a discussion of fundamental State laws, but it recommends that State laws be amended wherever necessary in order that every municipality may have the legal right to adopt whatever ordinances it sees fit for the improvement of the milk supply. The commission advocates that local health laws be carefully drawn with regard to their legality under the general laws of the localities to which they apply, since a decision against a milk law in one locality is liable to be used as a precedent against milk laws elsewhere.

\section{STANDARI) RULES AND REGULATIONS.}

The commission has drawn up a set of standard rules and regulations for the control of milk. These are the result of a study of the printed rules and regulations of the cities of the United States and of foreign countries and represent an immense amount of work on the part of the special committee of the commission to which the task was assigned. Some communities are in a position to adopt all of these rules and regulations at the present time, while other communities will be obliged to adopt a few rules at a time as public sentiment and local conditions warrant. It is realized that some of the rules may have to be modified to meet local conditions. It seems wise to the commission to divide the regulations into two parts: First, requirements, under which head are set down those provisions which are so fundamentally necessary that no community is justified in compromising on them; second, recommendations, under which head are set down provisions which are necessary for a good milk supply, but on which there can be a certain amount of latitude for compromise by those communities in which public sentiment is not ready to support more than a moderate degree of protection of human life.

\section{ADMLNISTRATIVE EQUIPMENT.}

Another prime requisite is that the administrative departments shall be adequately equipped with men, money, and laboratory facilities. In smaller communities cooperation between local boards of health to the extent of exchanging reports would eliminate much duplication. Where a community can not maintain a laboratory it can enter into laboratory arrangements with other communities, and several can combine in the use of a common laboratory. Much of the expense of tuberculin testing can be borne by the National and State Governments. The commission is of the opinion that results can not be expected from laws where there is not sufficient appropriation and 
no machinery for their enforcement. On this subject the commission passed a resolution as follows:

Whereas the appropriations generally made for the purposes of carrying on laboratory analyses of milk are now in most cases entirely inadequate: Therefore be it

Resolved, That this commission recommends for the consideration of the anthorities concerned an appropriation of funds commensurate with the importance of laboratory methods, which are of paramount importance in the hygienic control of the milk supply.

\section{CLASSIFICATION OF MILKS.}

There is no escape from the conclusion that milk must be graded and sold on grade, just as wheat, corn, cotton, beef, and other products are graded. The millk merchant must judge of the food value and also of the sanitary character of the commodity in which he deals. The high-grade product must get a better price than at present. 'The low-grade product must bring less. In separating milk into grades and classes the commission has encleavored to make its classification as simple as possible and at the same time to distinguish between milks which are essentially different in sanitary character.

In general two great classes of milk are recognized, namely, raw milk and pasteurized milk. Under these general classes there are different grades, as indicated in the report of the committee on classification.

\section{PASTEURIZATION.}

While the process of pasteurization is a matter which has attracted a great deal of attention in recent years, the commission has not entered into any discussion of its merits or demerits, but has given it recognition in its classiffcation as a process necessary for the treatment of milk which is not otherwise protected against infection.

The commission thinks that pasteurization is necessary for all milk at all times excepting certified milk or its equivalent. The majority of the commissioners voted in favor of the pasteurization of all milk. including certified. Since this was not unanimous, the commission recommends that the pasteurization of certified milk be optional.

\section{PASTEURIZING TEMIPERATURES.}

The destruction of the chemical constituents of milk by heat occurs at higher temperatures than those necessary for the destruction of the bacteria of infectious diseases transmissible by milk. (See chart in appendix.)

The commission passed a resolution regarding the temperature of pasteurization as follows:

That pasteurization of milk should be between the limits of $140^{\circ} \mathrm{F}$. and $155^{\circ}$ F. At $140^{\circ} \mathrm{F}$. the minimum exposure should be 20 minutes. For every degree abore $140^{\circ} \mathrm{F}$. the time may be reduced by 1 minute. In no case should the exposure be for less than 5 minutes.

In order to allow a margin of safety under commercial conditions, the commission recommends that the minimum temperature during the period of holding should be made $145^{\circ} \mathrm{F}$. and the holding time 20 minutes. Pasteurization in bulk when properly carried out has proven satisfactory, but pasteurization in the final container is preferable. 
The commission voted that all milk should be labeled and marked with the grade in which it is to be sold. In dating inilk uniform methods should be adopted for all grades of both raw milk and pasteurized milk, both using the day of the week or both using the day of the month. All milk should be dated uniformily with the date of delivery to the consumer. Raw milk should not be dated with the date of production while pasteurized milk is dated with the date of pasteurization, since this places certified milk at a disadvantage by making it possible for pasteurized milk of a lower grade to carry a later date. The stamping on the label of the day of the week is sufficient for dating.

\section{BACTERIA.}

The subject of bacteria in milk received more attention than any other matter brought before the commission. The commission recognizes that bacteria in milk in the majority of instances indicate dirt, or lack of refrigeration, or age, while in the minority of instances the bacteria of disease may be present. The routine laboratory methods for examining milk have as their purpose only the control over dirt, refrigeration, and age, and it is a rare thing for a laboratory to undertake the examination of milk for the bacteria of disease. Milk with a high bacterial count is not necessarily harmful, but when used as a food, particularly for children, is a hazard too great to be warranted. Milk with a high bacteria count, therefore, should be condemned. Milks with small numbers of bacteria are presumed to be wholesome, unless there is reasonable ground for suspecting that they have been exposed to contagion.

\section{BACTERIAL STANDARDS.}

The commission recognizes the difficulty in interpreting bacterial counts. At times misleading conclusions have been drawn from such counts. In establishing the bacterial standards for a city it is always necessary to take into consideration the necessary age of the milk and in lesser measure the distance hanled and methods omployed in its hauling. It will always be possible for a community which consumes milk produced on its own premises, or within 12 hours of its production, to insist upon and maintain a lewer bacterial standard than can one where the milk is hauled many miles into town in a wagon, to be consumed within 24 hours after it is produced. In like manner this second type of city can always maintain a lower bacterial standard than a city where the general milk supply is hauled by railroad long distances and is several days old when consumed. In drawing conclusions as to the relative efficacy of milk control in cities comparisons must be made between cities of the same class.

The commission deems it of the utmost importance that some standard method should be adopted for estimating and comparing the bacterial character of milks, since by this means only is it possible to grade and classify milks and to enforce bacterial standards. There is much diversity of opinion as to the best method of valuing bacterial counts. The average of a series gives results which are misleading about as frequently as otherwise. In the average a single high figure 
may unduly overbalance a large number of exceedingly low counts. There are objections to the use of the "median" or middle number when the counts are arranged in order of size, for the reason that the middle figure does not distinguish between two groups in one of which there may be some very high counts above the median and in the other of which there are none. The method of dividing results into groups as recommended by the American Public Health Association, while a step in the right direction, is cumbersome and does not clearly indicate whether a milk conforms or not to a given bacterial standard. In this dilemma the commission has adopted some special methods of stating the results of bacterial counts. It recommends the use of a single figure, called "the bacterial content," as the means of determining whether a milk conforms to given bacterial standards and for determining the class to which milk belongs. These methods are described in detail in the appendix.

The bacterial standards given in the report are the work of a special committee of bacteriologists who considered all of the bacterial standards now in use. It is believed that the standards suggested are fair and wise and give full consideration to the state of the industry and of public-health control. 'The commission believes that the adoption and enforcement of these bacterial standards will be more effective than any other one thing in improving the sanitary character of public milk supplies. The enforcement of these standards can only be carried out by the regular and frequent laboratory examinations of milks for the numbers of bacteria they may contain.

\section{CHEAICAI STANDARDS.}

The chemical standards suggested are the work of a special committee, composed of chemists, which has carefully considered the natural composition of milk and the Federal and State standards already established. The standard of 3.25 per cent fat and 8.5 per cent solids, not fat, here proposed is in accordance with the recommendations of the Association of Official Agricultural Chemists and has been adopted by the United States Department of Agriculture and by a larger number of States than has any other standard. The simplification of the Babcock test makes the determination of fats and solids not fat an easy procedure quickly applied. Such chemical examinations of milk can be readily adopted and executed by any health board laboratory at a very moderate expense. It is believed that such chemical standards as are suggested will inflict no real hardship on the milk producers of this country and that the provision regarding substandard milks is a liberal one.

\section{MICROSCOPIC EXAMINATION OF MILK.}

Some of the special methods of milk examination recently devised having as their object the determination of the numbers of bacteria directly by the use of the miscroscope, the presence of pus by sedimentation and microscopical examination, and the presence of gross dirt by filtration were deemed of such importance that the subjects were assigned to a special committee. The committee has made extensive studies of these methods, which are the subject of a special report. (See appendix.)

$56716^{\circ}-$ No. $78-12-2$ 


\title{
PUBLICITY.
}

The commission fully considered the matter of the publication of laboratory examinations of milk by city and town health authorities. When proper standards and regulations are established and adequate facilities furnished for laboratory work, it is believed that the laboratory tests will give an index of the character of the milk delivered to the public by milk sellers which is entirely fair and impartial. There can be no objection to publicity under such circumstances. It is an advantage to the seller of high-grade milk. It is an advantage to the consumer who desires to select a high-grade milk. It has much educational value both to producer and consumer. Therefore the commission recommends "that the reports of laboratory analyses of milk made by departments of health be regularly published."

\section{REPORT.}

\section{CLASSIFICATION OF MIILK.}

Milk should be graded and classified. The classification should be the same for both large and small cities and towns. Milk should be graded into four classes, as follows:

\author{
Class 1.-Certified milk or its equiralent. \\ Class B.-Inspected milk. \\ Class C.-Pasteurized milk. \\ Class D.-Milk not suitable for drinking purposes.
}

Crass A. Certified mith or its equivalent.-The use of the term certified should be limited to milk produced in conformity with the requirements of the American Association of Certified Milk Commissions.

Milk of an equivalent character should conform to the following requirements: It should be produced at dairies subjected to periorlic inspection and the products of which are subject to frequent analyses. The cows producing such milk must be properly fed and watered. free from tuberculosis as shown by the tuberculin test and physical examination by a qualified veterinarian, and from all other communicable diseases, and from diseases and conditions whatsoever likely to deteriorate the milk. They must be housed in clean, properly ventilated stables of sanitary construction. and must be kept clean. All persons who come in contact with the milk must exercise scrupulous cleanliness and must not harbor the germs of typhoid fever, tuberculosis, diphtheria, dysentery, scarlet ferer, and septic throat infections. or other infections liable to be conveyed by the milk. Milk must be drawn under all precantions necessary to avoid infection, and be immediately strained and cooled, placed in sterilized bottles, and kept at a temperature not exceeding $50^{\circ} \mathrm{F}$. until delivered to the consumer. Pure water, as determined by inspection and chemical and bacteriological examination, is to be provided for use thronghont the dairy farm and dairy. Milk of this class shonld contain less than 10,000 bacteria per cubic centimeter, and should not be more than 28 hours old when delivered.

Cliss B. Inspected mill:- This class should consist of clean raw milk from healthy cows, as determined by the tuberculin test and physical examination by a qualified veterinarian, and from dairies 
that score not less than 70 on the Government score card. The cows are to be fed, watered, housed, and milked under good conditions, but not necessarily equal to the conditions prescribed for class A. All persons who come in contact with the milk must exercise scrupulous cleanliness and must not harbor the germs of typhoid fever, tuberculosis, diphtheria, or other infectious diseases liable to be conveved by milk. This milk is to be delivered in sterilized containers and is to be kept at a temperature not exceeding $50^{\circ} \mathrm{F}$. until it reaches the consumer. It should contain less than 100,000 bacteria per cubic centimeters. Pasteurization of milk of this class is optional. If pasteurized it shall then be designated as "pasteurized inspected milk."

Cuass C. Pasteurized mill.-Milk from dairies not able to comply with the requirements specified for classes A and B should be pasteurized under official supervision before being sold, and should be sold under the designation "pasteurized milk." Milk for pasteurization should be kept at a temperature not exceeding $50^{\circ} \mathrm{F}$. at all times while in transit from the dairy farm to the pasteurizing plant. After pasteurization it should be placed in sterilized containers (if not pasteurized in such containers) and should be cooled at once to $50^{\circ} \mathrm{F}$. and kept below that temperature until delivered to the consumer. No cows in any way unfit for the production of milk for use by man, as determined by physical examination, shall be permitted to remain in any dairy producing milk of class C. Such milk before pasteurization should contain less than $1,000,000$ bacteria per cubic centimeter, and after pasteurization less than 50,000, and it should not contain colon bacilli in 1 cubic centimeter as determined by cultural methods. Pasteurized milk should be delivered to the consumer within less than 48 hours after pasteurization. The repasteurization of milk should be prohibited.

Cuass D. Milk not suitable for drinking purposes.-Milk containing over 1,000,000 bacteria per cubic centimeter, or from farms scoring less than 40 per cent, may be allowed to be sold for cooking and industrial purposes only after having been pasteurized or heated to a higher temperature. Such milk should be delivered in a distinctive container, and should not be allowed to be sold for drinking purposes.

CLASSIFICATION OF CREAM.

Cream should be classified into the same grades as milk, in accordance with the requirements for the grades of milk, with special bacterial standards which should not exceed 30,000 per cubic centimeter in the case of grade $\mathbf{A}$, and 300,000 per cubic centimeter in the case of grade B. Bacterial limits for grades $C$ and $D$ can not at the present time be specified.

\section{BACTERIOLOGICAL STANDARDS.}

Class A milk shall contain less than 10,000 bacteria per cubic centimeter.

Class B milk shall contain less than 100,000 bacteria per cubic centimeter.

Class C milk shall contain less than $1,000,000$ bacteria per cubic centimeter before pasteurization and less than 50,000 bacteria per 
cubic centimeter after pasteurization, and should not contain colon bacilli in 1 cubic centimeter as determined by cultural methods.

On the subject of laboratory examinations of milk for bacteria, the commission passed the following resolutions:

1. That the interests of public health lemand that the control of milk supplies shall include regular laboratory examinations of milk by bacteriological methods.

2. That among present available routine labolatory methods for determining the sanitary quality of milk the bacteria count occupies first place.

3. That bacteriological standards should be a factor in classifying or glading milks of different degrees of excellence.

4. That bacteriological examinations of milk are of importance at every stage of production and distribntion, but that in the establishment of grades and classes of raw milk such grates and classes should be based on the bacterial content of milk as offered for sale.

5. That there should be bacteriological standards for milk before it is yasteurized and for milk after it is pasteurized.

6. That the bacteria count of milk indicates its quality and history as it is molified by unusual contamination, improper handling, dirt, improper refrigeration, or age. The high count indicates the necessity of investigation and inspection in order that remedies may be applied.

7. That there be adopted as standards for making the bacteria count the standard methols of the American Public Health Association, laboratory section, recommending, however, the following amenduents:

A. The methods of taking samples for laboratory tests for bacterial counts should be the same and uniform for all grades and classes of milk.

B. That $1 \frac{1}{2}$ per cent agar be used instead of 1 per cent agar.

C. 'That incubation of plate cultures be made at $37^{\circ} \mathrm{C}$. for $48 \mathrm{hours}$, and that thel'e be no option.

D. 'That the minimum number of bacteria tests of milk necessary to warrant the publication of results be made four consecutive bacteria counts of separate samples within a period of not more than four weeks.

CHEMICAL STANDARDS.

Cov's milk.-Standard milk should contain not less than 8.5 per cent of milk solids not fat and not less than 3.25 per cent of milk fat.

Skim mill.--Standard skim milk should contain not less than 8.75 per cent of milk solids.

C'ream.-Standard cream contains not less than 18 per cent of milk fat and is free from all constituents foreign to normal milk. The percentage of milk fat in cream over or under that standard should be stated on the label.

Buttermill:-Buttermilk is the product that remains when fat is removed from milk or cream, sweet or sour, in the process of churning. Standard buttermilk contains not less than 8.5 per cent of milk solids. When milk is skimmed, soured, or treated so as to resemble buttermilk, it should be known by some distinctive name.

\section{HOMOGENIZED MILK OR CREAM.}

The commission is of the opinion that in the compounding of milk no fats other than milk fats from the milk in process should he user and that no substance foreign to milk should be added to it. The commission is opposed to the use of condensed milk or other materials for the thickening of cream unless the facts are clearly set forth on the label of the retail package. Regarding the process of homogenizing the commission resolved as follows:

That homogenized milk or cream should be so marked, stating the percentage of fat that it contains. 


\section{ADJUSTED MILKS.}

On the question of milks and creams in which the ratio of the fats to the solids not fat has been changed by the addition to or subtraction of cream or milk fat the commission has hesitated to take a position. On the one hand they are in favor of every procedure which will increase the market for good milk and make the most profitable use of every portion of it. On the other, they recognize the sensitiveness of milk, the ease with which it is contaminated, and the difficulty of controlling, standardizing, skimming, homogenizing, souring, etc., so that contaminations do not occur and inferior materials are not used. On this subject the commission passed a resolution presented by a special committee as follows:

- Milk in which the ratio of the fats to the solids not fat has been changed by the addition to or subtraction of cream should be labeled "adjusted milk"; the label should show the minimum guaranteed percentage of fat and shou?d comply with the same sanitary or chemical requirements as for milk not so stindardized or modified.

REGILATION OF MARTET MIILK ON BASIS OF GUARANTEED PERCENTAGE COMPOSITION.

1. Sellers of milk should be permitted choice of one of two systems in handling market milk. Milk can be sold, first, under the regular standard, or, second, under a guaranteed statement of composition.

2. Any normal milk may be sold if its per cent of fat is stated. In case the per cent of fat is not stated, the sale will be regarded as a violation unless the milk contains at least 3.25 per cent of milk fat.

3. As a further protection to consumers, it is desirable that when the guaranty system is used there be also a minimum guaranty of milk solids not fat of not less than 8.5 per cent.

4. Dealers electing to sell milk under the guaranty system should be required to state conspicuously the guaranty on all containers in which such milk is handled by the dealer or delivered to the consumer.

5. The sale of milk on a guaranty system should be by special permission obtained from some proper local authority.

\section{STANDARD RULES FOR THE PRODUCTION, HANDLING, AND DISTRI-} BUTION OF MILk.

As a basis for the promulgation of rules and recommentations governing the production, handling, and distribution of milk, it is recognized that we have to deal with two kinds of milk, raw and pasteurized, although there may be several grades of each of these two kinds. In order for any grade to be safe, it is recommended that the regulations herein set forth under the heading "Requirements" whould be enforced. The regulations herein set forth under the heading "Recommendations" should be adopted wherever practicable as a means of improving the milk supply above the actual point of safety. (The term " milk" shall be construed to include the fluid derivatives of milk wherever such construction of the term is applicable.) 


\section{LICENSES.}

\section{REQUIREMENTS.}

No person shall engage in the sale, handling, or distribution of milk in - until he has obtained a license therefor from the health authorities. This license shall be renewed on or before the 1st day of for cause. of each year and may be suspended or revoked at any time

\section{RECOMMENDATIONS.}

The application for the license shall include the following statements:

(1) Kind of milk to be handled or sold.

(2) Names of producers with their addlesses and permit numbers.

(3) Names of middlemen with their addresses.

(4) Names and addresses of all stores, hotels, factories, and restaurants it which milk is delivered.

(5) A statement of the approximate number of quarts of milk, cream, buttermilk, and skim milk sold per day.

(6) Source of water supply at farms and bottling plants.

(7) P'ermission to inspect all local and out-of-town premises on which milk is produced and handled.

(8) Agreement to abide by all the provisions of State and locil regulations.

\section{PERMITS.}

\section{REQUIREMENTS.}

No person shall engage in the production of milk for sale in nor shall any person engage in the handling of milk for shipment into _ until he has obtained a permit therefor from the health authorities. This permit shall be renewed on or before the 1st day of — of each year and may be suspended or revoked at any time for cause.

\section{Raw Milk.}

COW STABLES.

REQUIRTMENTS.

1. They shall be used for no other purpose than for the keeping of cows, and shall be light, well rentilated, and clean.

2. They shall be ceiled overhead if there is a loft above.

3. The floors shall be tight and sound.

4. The gutters shall be water-tight.

RECOMMTNDATIONS.

1. The window area shall be at least 2 square feet per 500 cubic fect of air space and shall be uniformly distributed, if possible. If uniform distribution is impossible, sufficient additional window area must be provided so that all portions of the barn shall be adequately lighted.

2. The amount of air space shall be at least 500 cubic feet per cow, and adequate rentilation besides windows shall be provided.

3. 'The walls and ceilings shall be whitewashed at least once every six months, unless the construction renders it unnecessary, aul shall be kept free from cribwebs and dirt.

4. All manure shall be removed at least twice daily and disposed of so as not to be a source of danger to the milk either as furnishing a Ireeding place for flies or otherwise.

5. Horse manure shall not be used in the cow stable for any purpose. 
MILT ROOM.

REQUIREMENTS.

Every milk farm shall be provided with a milk room that is clean, light, and well screened. It shall be used for no other purpose than for the cooling, bottling, and storage of milk and the operations incident thereto.

\section{RECOMMENDATIONS.}

1. It shall have no direct connection with any stable or dwelling.

2. The floors shall be of cement or other impervious material, properly graded and drained.

3. It shall be provided with a sterilizer unless the milk is sent to a bottling plant, in which case the cans shall be sterilized at the plant.

4. Cooling and storage tanks shall be drained and cleaned at least twice each week.

5. All drains shall discharge at least 100 feet from any milk house or cow stable.

CONS.

REQUIREMENTS.

1. A physical examination of all cows shall be made at least once every six months by a veterinarian approved by the health anthorities.

2. Every diseased cow shall be removed from the herd at once and no milk from such cows shall be offered for sale.

3. The tuberculin test shall be applied at least once a year by a veterinarian approved by the health authorities.

4. All cows which react shall be removed from the herd at once, and no milk from such cows shall be sold as raw milk.

5. No new cows shall be added to a herd until they have passed a physical examination and the tuberculin test.

6. Cows, especially the udders, shall be clean at the time of milling.

7. No milk that is obtained from a cow within 15 days before or 5 days after parturition, nor any milk that has an unnatural odor or appearance, shall be sold.

8. No unwholesome food shall be used.

RECOMMENDATIONS.

1. Every producer shall allow a reterinariar employed by the health authorities to examine his herd at any time under the penalty of having his supply excluded.

2. Certificates showing the results of all examinations shall be fled with the health authorities within 10 days of such examinations.

3. The tuberculin tests shall be applied at least once every six months by a reterinarian approved by the health authorities, unless on the last prerious test no tuberculosis was present in the herd or in the herds from which new cows were obtained, in which event the test maly be postponed an additional six months.

4. Charts showing the results of all tuberculin tests shail be filed with the health authorities within 10 days of the date of such test.

5. The udders shall be washed and wiped before milking.

EMPLOYEES.

REQUIREMENTS.

1. All employees connected in any way with the production and handling of milk shall be personally clean and shall wear clean outer garments.

2. The health authorities shall be notified at once of any communicable disease in any person that is in any way connected with the 
production or handling of milk, or of the exposure of such person to any communicable clisease.

3. Milking shall be done only with dry hands.

RECOM MENDATIONS.

1. Clean suits shall be put on immediately before milking.

2. The hands shall be washed inmediately before milking each cow, in order to aroid conveyance of infection to the milk.

UTENSILS.

REQUIRLMENTS.

1. All utensils and apparatus with which milk comes in contact shall be thoroughly washed and sterilized, and no milk utensil or apparatus shall be used for any other purpose than that for which it was designed.

2. The owner's name, license number, or other identification mark, the nature of which shall be made known to the health authorities, shall appear in a conspicuous place on every milk container.

3. No bottle or can shall be removed from a house in which there is, or in which there has recently been, a case of communicable disease until permission in writing has been granted by the health authorities.

4. All metal containers and piping shall be in good condition at all times. All piping shall be sanitary milk piping, in couples short enough to be taken apart and cleaned with a brush.

5. Small-top milking pails shall be used.

RECOMMENDATIONS.

1. All cans and bottles shall be cleaned as soon as possible after being emptied.

2. Frery conreyance used for the transportation or delivery of milk, jublic. cinrier's excejted, shall bear the owner's name. milk-iicense number, and business address in uncondensed gothic characters at least 2 inches in height.

MILK.

REQUIREMENTS.

1. It shall not be strained in the cow stable, but shall be removed to the milk room as soon as it is drawn from the cow.

2. It shall be cooled to $50^{\circ} \mathrm{F}$. or below within two hours after it is drawn from the cow and it shall be kept cold until it is delivered to the consumer.

3. It shall not be adulterated by the addition to or the subtraction of any substance or compound, except for the production of the fluid derivatives allowed by law.

4. It shall not be tested by taste at any bottling plant, milk house, or other place in any way that may rencler it liable to contamination.

5. It shall be bottled only in a milk room or bottling plant for which a license or permit has been issued.

6. It shall be delivered in bottles, or single service containers, with the exception that 20 quarts or more may be delivered in bulk in the following cases: 
(a) To establishments in which milk is to be consumed or used on the premises.

(b) To infant-feeding stations that are under competent medical supervision.

7. It shall not be stored in or sold from a living room or from any other place which might render it liable to contamination.

\section{RECOMMENDATIONS.}

1. It shall be cooled to $50^{\circ} \mathrm{F}$. or below immediately after milking and shall be kept at or below that temperature until it is delivered to the consumer.

2. It shall contain no visible foreign material.

3. It shall be labeled with the date of production.

\section{RECEIVING STATIONS AND BOTTLING PLANTS.}

REQUIREMENTS.

1. They shall be clean, well screened, and lighted, and shall be used for no other purpose than the proper handling of milk and the operations incident thereto, and shall be open to inspection by the health authorities at any time.

2. They shall have smooth, impervious floors, properly graded and drained.

3. They shall be equipped with hot and cold water and steam.

4. Ample provision shall be made for steam sterilization of all utensils, and no empty milk containers shall be sent out until after such sterilization.

5. All utensils, piping, and tanks shall be kept clean and shall be sterilized daily.

\section{RECOMMENDATIONS.}

1. Containers and utensils shall not be washer in the same room in which milk is handled.

\section{STORES.}

REQUIREMENTS.

1. All stores in which milk is handled shall be provided with a suitable room or compartment in which the milk shall be kept. Sairl compartment shall be clean and shall be so arranged that the milk will not be liable to contamination of any kind.

2. Milk shall be kept at a temperature not exceeding $50^{\circ} \mathrm{F}$.

\section{RECOMMENDATIONS.}

1. Milk to be consumed off the premises may be sold from stores only in the original unopened package.

\section{GENERAL REGULATIONS.}

REQUIREMENTS.

1. The United States Burean of Animal Industry score card shall be used, and no milk from a dairy that scores below 70 on such card shall be sold.

2. Every place where milk is produced or handled and every conveyance used for the transportation of milk shall be clean.

$56716^{\circ}-$ No. $78-12-3$ 
3. All water supplies shall be from uncontaminated sources and from sources not liable to become contaminated.

4. The license or permit shall be kept posted in a conspicuous place in erery establishment for the operation of which a milk license or permit is required.

5. No milk license or permit shall at any time be used by any person other than the one to whom it was granted.

6. No place for the operation of which a license or permit is granted shall be located within 100 fect of a privy or other possible source of contamination, nor shall it contain or open into a room which contains a water-closet.

7. No skim milk or buttermilk shall be stored in or sold from cans or other containers unless such containers are of a distinctive color and permanently and conspicuously labeled "skim milk" or "buttermilk," as the case may be.

8. No container shall be used for any other purpose than that for which it is labeled.

\section{RECOMAENDATIONS.}

1. Ice used for cooling purposes shall be clean and uncontaminated.

2. No person whose presence is not required shall be permitted to remain in any cow stable, milk house. or bottling room.

SUBNORMAL MILK.

REQUIREMENTS.

1. Natural milk that contains less than 3.25 per cent, but more than 2.5 per cent milk fat, and that complies in all other respects with the requirements above set forth, mar be sold, provided the percentage of fat does not fall below a definite percentage that is stated in a conspicuous manner on the container; and further provided that such container is conspicuously marked "substandard milk."

CREAM.

REQUIREMTNTS AND RECOMMENDATIONS.

1. It shall be obtained from milk that is produced and handled in accordance with the provisions hereinbefore set forth for the production and handling of milk.

\section{STANDARDS FOR MILK. \\ REQUIREMENTS.}

1. It shall not contain more than 100,000 bacteria per cubic centimeter.

2. It shall contain not less than 3.25 per cent milk fat.

3. It shall contain not less than 8.5 per cent solids not fat.

RECOMMEENDATIONS.

1. The bacterial limit shall be lowered if possible. 
STANDARDS FOR CREAM.

REQUIREMENTS.

1. It shall not contain more than 300,000 bacteria per cubic centimeter.

.2. It shall contain not less than 18 per cent milk fat.

RECOMMENDATIONS.

Sime as abore for milk.

STANDARDS FOR STIM MILK.

REQQUIREMENTS.

1. It shall contain not less than 8.75 per cent milk solids.

2. Control of sale of skim milk: Whether skim milk is sold in wagons or in stores, all containers holding skim milk should be painted some bright, distinctive color and prominently and legibly marked "skim milk." When skim milk is placed in the buyer's container, a label or tag bearing the words "skim milk" should be attached.

Pasteurized Milk.

Pasteurized milk is milk that is heated to a temperature of not less than $140^{\circ} \mathrm{F}$. for not less than 20 minutes, or not over $155^{\circ} \mathrm{F}$. for not less than 5 minutes, and for each degree of temperature over $110^{\circ} \mathrm{F}$. the length of time may be 1 minnte less than 20. Said milk shall be cooled immediately to $50^{\circ} \mathrm{F}$. or below and kept at or below that temperature.

COW STABLES.

REQUIREMENTS.

The same as for the production of raw milk.

RLCOMMENDATIONS.

The same as for the production of raw milk.

MILK ROOM.

REQUIREMENTS.

The same as for the prodnction of raw milk.

RECOMMENDATIONS.

The same as for the production of raw milk.

cows.

REQUIREMENTS.

The same as for the production of raw milk, with the exception of the sections relating to the tuberculin test.

RECOMMENDATIONS.

That no cows be added to a herd excepting those found to be free from tuberculosis by the tuberculin test. 


\section{EMPLOYEES.}

REQUIREMENTS.

The same as for the production of raw milk.

$$
\text { RECOMMENDATIONS. }
$$

The same as for the production of raw milk.

\section{UTENSILS.}

REQUIREMENTS.

The same as for the production of raw milk.

$$
\text { RECOMIIENDATIONS. }
$$

The same as for the production of raw milk.

\section{MILI FOR PASTELRIZATION.}

REQUIREMENTS.

1. The same as for the production of raw milk, with the exception of sections 1,2 , and $6 b$.

2. It shall be cooled to $60^{\circ} \mathrm{F}$. or below within two hours after it is clrawn from the cow, and it shall be held at or below that temperature until it is pasteurized. After pasteurization, it shall be held at a temperature not exceeding $50^{\circ} \mathrm{F}$. until delivered to the consumer.

3. Pastemized milk shall be distinctly laheled as such, together with the temperature at which it is pasteurized, and the shortest length of exposure to that temperature and the date of pasteurization.

\section{RECOMMIENDATIONS.}

1. No milk shall be repasteurizet.

2. The requirements gorelnimg the production and handling of milk for p:steurization should be raised wherever practicable.

\section{PASTEURIZING PLANTS.}

REQYIREMENTS.

The same as moler "Receiving stations and bottling plants" for" raw milk.

$$
\text { RFCOMMENDAIIUNS. }
$$

"The same as under "Receiving stations and bottling plants" for raw milk.

STORES.

REQUIREMENTS.

The same as for raw milk.

RECOMMENDATIONS.

The sime as for raw milk. 
REQUIREMENTS.

1. The same as for raw milk with the exception that the minimum dairy score shall be 40 , and no milk from a dairy that scores below 40 shall be pastemrized for sale, except for industrial purposes.

2. Milk from cows that have been rejected by the tuberculin test, but which show no physical signs of tuberculosis, as well as those which have not been tested, may be sold provided that it is produced and handled in accordance with all the other requirements herein set forth for pasteurized milk.

3. Ice used for cooling purposes shall be clean.

RECOMMENDATIONS.

The same as for raw milk.

\section{PASTEURIZED CREAM.}

REQUIREMENTS.

1. It shall be obtained only from mills that could legally be sold as milk under the requirements hereinbefore set forth.

2. Pasteurized cream, or cream separated from pasteurized nilk, shall be labeled in the mamner herein provided for the labeling of pasteurized milk.

\section{STANDARDS FOR PASTEURIZED MILK.}

REQUIREMENTS.

1. It shall not contain more than $1,000,000$ bacteria per cubic centimeter before pasteurization, nor over 50,000 when delivered to the consumer, and no colon bacilli in 1 cubic centimeter as determined by cultural methods.

2. The standards for the percentage of milk fat and of total solids shall be the same as for raw milk.

\section{RECOMMENDATIONS.}

1. The limits for the bacterial count before pastenrization and after pasteurization should both be lowered if possible.

STANDARDS FOR PASTEURIZED CREAM.

REQUIREMENTS.

1. No cream shall be sold that is obtained from pasteurized milk that could not be legally sold under the provisions herein set forth, nor shall any cream that is pasteurized after separation contain an excessive number of bacteria.

2. The bacterial count of pasteurized cream shall not exceed 100,000 bacteria pel' cubic centimeter when delivered to the consumer.

3. The percentage of milk fat shall be the same as for raw cream.

\section{Penalty.}

Every milk ordinance should contain a penalty clause. 


\section{APPENDIX.}

REPORT OF THE COMMTTEE UPON THE MICROSCOPIC EXAMNATION OF MILI AND UPON THE DETERMINATION OF THE DIRT IN MILIS.

Inasmuch as the subjects referred to this committee are in some respects new to some members of the commission, the report of this committee is presented in two parts. In the first part are given the important facts concerning the method and the utility of a microscopic examination of milk, and in the second part are presented a few resolutions for consideration by the committee. The data upon which this report is based is partly derived from special work by members of the committee and partly from correspondence and publiched papers. Letters have been addressed to all laboratories where these methods hare been in use, so far as the addresses conld be obtained, and from the replies received the following conclusion has been reacherl:

1. The microscopic examination of raw milk has been somewhat widely adopted, but apparently only in a few places has it been extensively used. In at least two laboratories where it has been tried, it has been given up as nmeliable; but in general those who have used the method most are most enthusiastic as to its value.

2. There are two different methods of making a microscopic examination of milk:

(a) The use of centrifugal machine by the Stewart-Slack method. This method inrolves the centrifugalization of 1 or 2 cubic centimeters of milk and smearing of the sediment upon a slide, subsequently staining the same, and is so well known that it is mnecessary to describe it in detail here. It is the method that has been most commonly used. The results of this method vary consiclerably with details of individual manipulation, with the speed of the centrifugal machine, with the time allowed for centrifugalization, and with other individual factors. As a result, findings of one laboratory can not be commonly compared accurately with those of another, but they are fairly miform when compared with each other.

(b) The direct examination of milk by the Prescott-Breed method. The details of this method are found in the Cent. f. Bact. 11. XXX, p. 337, 1911, but since it is somewhat new a brief description of it will be here given. A capillary tube is prepared, arranged to receive a rubler bulb at one end and marked carefully to delirer" one onehundredth of a cubic centmeter. After a most thorough mixing of the milk. one one-hundredth of a cubic centimeter is removed with the sterilized pipette and spread miformly orer a square centimeter on an ordinary microscopic slide. It is allowed to dry and is fixed with methyl alcohol, after which the fat is dissolved from it by the use of xylol. The smear is then stained either with methyline blue or preferably with one of the blood stains, the Jenner stain or Wright stain being useful for this purpose. If the staining is so deep as to make the specimen too opaque for proper study, it is slightly decolorized with alcohol which remores the stain from the general sediment more readily than it does from the bacteria or the tissue cells. The stained smear is studied under a twelve-inch immersion. The draw tube of the immersion is adjusted so that the field of the microscope covers exactly 15 millimeters and under these circumstances the 
number of bacteria present in the one one-hundredth of a cubic centimeter is exactly 5,000 times the number found in a microscopic field. The counting of a large number of fields (100 fields) and areraging the results multiplied by this number will therefore give approximately the number of cells or bacteria contained in a one one-hundredth cubic centimeter of milk.

This method has the advantage of eliminating all of the errors that are associated with the irregularity in the action of the centrifugal machine and many of the other individual errors connected with the Stewart-Slack method. On the other hand, it has the disadvantage of examining only a small quantity of milk, one one-hundredth of a cubic centimeter being hardly a fair sample. This disadvantage, however, may be met by making a very thorough mixture of the milk before sampling and by making the examination in duplicate. A second disadvantage is the large multiplier that has to be used to reduce the results to 1 cubic centimeter. This, of comrse, very greatly increases any error that may appear in the observation and introdnces an error the extent of which can not yet be stated accurately. It may in a measure be met by making the examination in duplicato and by areraging a large number of plate counts.

3. The chief advantages derived from the microscopic examination of milk are due to the quickness of the method:

(a) It makes possible the rapid discarding of poor samples of milk, since reports upon it are possible within a very short time.

(b) The quickness with which an examination can be made makes it possible for a single laboratory to examine many more samples of milk than by the older plate method, one person being able to examine and report upon 50 to 100 samples in a half day, and to make the reports upon the same day that the milk is collected.

4. The microscopic study of milk gives information upon the following points:

(a) The abundance of cells which are present in the milk.

(b) The chmping of these cells, which is frequently noticeable in the centrifugal slime but which is rarely if erer seen in milk that is examined by the direct method above mentioned.

(c) The bacterial count.

(d) The presence of chain-forming streptococci (in this report when the term streptococci is used, reference is made to chain-forming organisms with at least six elements in a chain).

(e) General information concerning the nature of the dirt and the sonrce of the bacteria in the milk. With a little experience one can distinguish certain types of bacteria which comes from farm dirt from those that come from unclean vessels.

5 . The estimation of the number of bacteria in milk by microscopic study has the following advantages and disadvantages: low

(a) It is of no value when the number of bacteria in the milk is

(b) The microscopic examination gives numbers of bacteria vastly higher than those given by the plate method. (In a series of $20 \mathrm{com}$ parative tests by one member of the committee there was found an average of 5,000 bacteria by the plate method, 700,000 bacteria by the Stewart-Slack method, and 5,000,000 bacteria by the PrescottBreed method of microscopic examination.) 
(c) In determining the total number of bacteria in milk the microscopic-examination is far more accurate than the plate method, since it gives practically all of the bacteria present, while the plate method gives only those that grow in special media under special conditions. The microscope, however, fails to distinguish between living and dead bacteria.

(d) The Stewart-Slack method of examining milk is of great practical use in those cities which have a bacterial standard of 500,000 , since it quickly detects milk which contains bacteria more than this limit without the necessity of making plate count. For" samples that contain about 500,000 or less it is necessary to make a plate count in order that the result may be reliable.

(e) The data at hand are as yet insufficient to determine the factor by which the milk could be condemned by the Prescott-Breed method. Data at present at hand would seem to indicate that nearly all samples of milk would approach or surpass this limit of 500,000 when the bacteria are determined by the direct method of examination of Prescott-Breed.

(f) No constant ratio can be found between the number of bacteria disclosed by the microscope and the number found by the plate count. There is a general parallel but with many irregularities.

6. No method has yet been accepted for accurately distinguishing between the pus cells and other cells that mav be in the milk that do not have an origin in inflammatory conditions. Some regard all noticeably clumped cells as indicating pus, stating that upon proper incubation, all such clumpings may be found to be accompanied by chain-forming streptococci. Others regard all polymorpho-nuclear neutrophilic cells as pus. Most, however, at the present time fail to recognize any method of clearly distinguishing pus from tissue cells.

7. A general consensus of opinion has been reached that a high cell count should not alone condemn milk, although it is a matter for suspicion. The cell count varies with the same cow upon different days and it may be increased by simply manipulating the udders. Some believe that clumped cells always indicate an inflammatory condition.

8. A high cell count accompanied by streptococci apparently always indicates ndder tronbles. In many cases these have been followed up to the dairv, and where this has been done it is almost always possible to find the source in some cow suffering from some trouble in its udders.

9. More data is needed before it can be definitely stated whether ill health in children can be traced to milk that would be condemned by the microscope, although this has apparently been done in some cases.

10. At the present time, it is impossible to agree upon any standard for condemning milk by cell count beyond the general rule that a high cell count accompanied by streptococci indicates an inflammatory condition or otherwise diseased udder's.

11. Where the source of the milk is known, microscopic method of study is of great value in picking out animals with diseased udders. It is of a special help in directing attention to a herd that needs inspection, and has been extensively and satisfactorily used in this way. 
'In market milk, it is of great value where the source of the milk is known and can be reached, and its chief value is in finding the location of troubles rather than in condemning milk.

12. Concerning the value of the microscopic examination of milk, there are wide differences of opinion among those who have been using it. A few regard it as of little value and have discarded it entirely. Some have thought it of some value, but much less than the bacteriological plate count. Others regard it of more value than the plate count; and some have looked upon it as of so much value as to lead them to substitute it for the older method of bacteriological examination by plates, this latter method of examining having been quite abandoned. The claim is made in these cases that it gives better and quicker results and has been found of practical value in controlling the milk supply by pointing out the sources of trouble. All who have used this method recognize that it gives valuable data.

13. Concerning the dirt test, the committee would make the following statement: Of the several methods of determining the presence of dirt in milk the committee believe that the most valuable is that of filtering it through a cotton disk. This committee would suggest that a standard disk of an inch in diameter be selected for the filtering of a quart of milk, and proportionate-sized disk for smaller amounts of milk. The Lorenze apparatus is a convenient filter for filtering milk through a cotton disk; but various other types than that distinctly known by this name are equally satisfactory. A Gooch crucible may be used conveniently or any other device in which the cotton disk is supported upon a gauze and in such position that milk can be readily filtered through it. To be most efficient, the cotton disk should be subsequently dried and sent to the individual dairyman.

In order to have the best results, the most desirable plan is to do the filtering in the dairy immediately after milking. For this purpose batteries of filters are needed, and these must be warmed in cold weather in order that milk shonld pass through them readily. If these are used in the dairy, the results thus demonstrated to the dairyman are very convincing. The test is quick and simple and is proving very useful in locating unclean methods. It is much less cumbersome than the somewhat more expensive method of measuring the amount of dirt, and although it does not give a quantitative, but only comparative result, it is as useful for the purpose of detecting and remedying unclean conditions as the more slow and more expensive quantitative methods.

From these data the committee would present the following recommendations:

\section{RECOMLMENDATIONS.}

1. The direct microscopical examination of raw milk gives very valuable information, since it presents in a few moments a graplic picture of the bacterial content as well as the number of cells and offers a prompt method of excluding some samples of milk which are manifestly unfit for use, doing this promptly. To give the most valuable results, the committee would recommend the use of some good blood stain like the Jenner or the Wright stain. 
2. Because of the irregularities in methods and results, no standard can yet be given for grading. milk by the microscopic examination. Special attention is recommended to the presence of polymorphonuclear neutrophilic cells. A high cell count alone is not sufficient to condemn milk, but if accompanied by chain-forming streptococci it is an indication of udder troubles. The presence of streptococci alone is also sufficient to suggest the same conclusion. The microscopic examination is therefore of great use in picking out animals with diseased udders for the purpose of remoring them from the dairy herd after a proper examination of individual cows.

3. The data as yet accumulated are insufficient to determine whether the examination of milk by the centrifugal method of the Stewart-Slack type or the direct examination by the Prescott-Breed method gives the most reliable results.

4. The total numbers of bacteria found by the microscopic examination are so out of proportion to those given by those of the plate method that no ratio can be at present drawn between them.

5 . The data which have as yet been collected are insufficient to determine whether the microscope examination of pasteurized milk is of any value.

6. The determination of dirt by filtering a quart of milk through a cotton disk of an inch in diameter is advised as of the greatest value in detecting uncleanly conditions and in conveying a most graphic lesson of the need of cleanliness to the dairvman. Preferably this sliould be done in the dairy where feasible.

\section{METHODS OF REPORTING BACTERIAL COUNTS.}

\section{CLASSIFICATION OF DEALERS' MILIKS.}

The commission recommends the use of North's modification of Lery's method of giving each bacterial count a rating value. This̀ modification consists in the use of such values as can be obtained from a parabolic curve having as ordinates the ratings and as abscissas the bacteria counts. The final statement of a series of bacterial counts is given as a single figure which expresses the sanitary character of the milk in terms of bacteria per cubic centimeter. This figure, it is recommended, shall be known as the "bacterial content."

To warrant a statement of the class or grade in which a given milk belongs, at least four consecutive counts should be made of separate samples of milk taken within a period of not more than four weeks.

All laboratory workers are familiar with the fact that the differences in sanitary importance of high and low bacterial counts are not proportional to the numerical differences. It is recognized that bacteria multiply in geometric progression. A single germ may divide, under favorable conditions, about once every half hour, so that from 1 it will have increased to $281,474,976,710,656$ within 24 hours. This means that under favorable conditions, if there were no interruptions and no deaths, 1 germ in a 40-quart can of milk might multiply in 24 hours, so that 1 cubic centimeter of milk would contain over $7,438,000,000$. The ability of some bacteria to multiply with extreme rapidity is the reason why high counts should not be given the same value which is given to low counts. 
The method proposed for stating the results of bacterial counts aims to recognize all high counts but at the same time to prevent them from misrepresenting the real character of the milk. The method may at first seem complicated because of its use of higher mathematics, but as a matter of fact is extremely simple.

THE PARABOLIC CURVE.

Without going into a discussion of the properties of the different mathematical curves, it can be stated that a parabola is a regular curve, which increases its distance far more rapidly in a horizontal direction than in a vertical direction, or vice versa, and, consequently, lends itself to the conditions of the problem which faces the bacteriologist who has, on the one hand, bacteria counts which increase enormously in the higher figures, while on the other he has values which he desires to attach to the same, which do not differ so enormously. The values for bacteria counts obtained from the parabola are as follows:

Where

$$
\begin{aligned}
& y^{2}=\times 1 / 100 . \\
& x=\text { bacteria count. } \\
& y=\text { rating corresponding. }
\end{aligned}
$$

\begin{tabular}{|r|r||r|r|r|r|}
\hline $\begin{array}{c}\text { Bacteria } \\
\text { counts. }\end{array}$ & $\begin{array}{c}\text { Normal } \\
\text { rating. }\end{array}$ & $\begin{array}{c}\text { Bacteria } \\
\text { counts. }\end{array}$ & $\begin{array}{c}\text { Normal } \\
\text { rating. }\end{array}$ & $\begin{array}{r}\text { Bacteria } \\
\text { counts. }\end{array}$ & $\begin{array}{r}\text { Normal } \\
\text { rating. }\end{array}$ \\
\cline { 2 - 5 } 100 & 1.00 & 9,000 & 9.5 & 300,000 & 54.8 \\
200 & 1.41 & 10,000 & 10.0 & 400,000 & 63.2 \\
300 & 1.73 & 15,000 & 12.3 & 500000 & 70.8 \\
400 & 2.00 & 20,000 & 14.1 & 600.000 & 77.5 \\
500 & 2.24 & 25,000 & 15.8 & 700.000 & 83.7 \\
600 & 2.45 & 30,000 & 17.3 & 800,000 & 89.5 \\
700 & 2.65 & 35,000 & 18.7 & 900,000 & 95.0 \\
800 & 2.83 & 40,000 & 20.0 & $1,000.000$ & 100.0 \\
900 & 3.00 & 45,000 & 21.2 & $2,000,000$ & 141.0 \\
1,000 & 3.16 & 50,000 & 22.4 & $3,000,000$ & 173.0 \\
2,000 & 4.47 & 60,000 & 24.5 & $4,000,000$ & 200.0 \\
3,000 & 5.48 & 70,000 & 26.4 & $5,000,000$ & 224.0 \\
4,000 & 6.32 & 80,000 & 28.3 & $6,000,000$ & 245.0 \\
5,000 & 7.08 & 90,000 & 30.0 & $7,000,000$ & 265.0 \\
6,000 & 7.75 & 100,000 & 31.6 & $8,000,000$ & 283.0 \\
7,000 & 3.37 & 200,000 & 44.7 & $9,000,000$ & 300.0 \\
8,000 & 8.95 & 250,000 & 50.0 & $10,000,000$ & 316.0 \\
\hline
\end{tabular}

From the diagram of the parabolic curve shown on page 699 the values in the table given were taken. For any bacterial count a corresponding value can be found by observing the point on the curve intersected by the line leading upward from the bacterial count and following the line of rating value which leads to the right or left at this point. Thus the line leading upward from 10,000 bacteria strikes the curve at a point throngh which passes the line leading to the left having rating value 10 , and bacterial line 40,000 meets curve at point intersected by line of rating value 20 ; bacterial line $1,000,000$ meets rating line 100 .

In the figure the curve from 40,000 to 100,000 bacteria is much condensed to save space, and from 100,000 to 1.000,000, and again to $4,000,000$, is still further condensed; these shortenings account for disjointed appearance. 
This table is used as follows: Assume that a health board labcratory makes four consecutive examinations of the milk of a single dealer, and that these are as follows: 25,000, 70,000, 250,000, and $5,000,000$. It desires to determine in what class this milk belongs. To 'xpress the character of the milk in a single figure set opposite each bacteria count the normal rating value found in the above table. This would be as follows:

\begin{tabular}{|c|c|}
\hline Bacteria count. & Normal ratings. \\
\hline 25,000 & 15.8 \\
70,000 & 26.4 \\
250,000 & 50.0 \\
$5,000,000$ & $\frac{224.0}{316.2}$ \\
& $\frac{\text { 4) }}{79.0}=600,000+$ \\
\hline
\end{tabular}

After the normal ratings are obtained for eich figure, they are added together and areraged, as shown above, giving the average rating 79. I gain referring to the table it will be observed that the nearest figure in the normal rating column is 77.5 , opposite which is the bacteria count of 600.000 . Consequently, the final character of the milk will be expressed by the figure 600,000 bacteria per cubic centimeter. Pursuing this system with all milks makes it possible to express their character in a single figure in terms of bacteria, which it is suggested should be called "the bacterial content."

TIE RATING OF A CITY'S ENTIRE MILK SUPPLY.

In the annual report of a city's department of health it is often desirable to compare the results of one year's work with another, or to compare one city's standing with that of another. For these purposes the commission recommends the use of the Levy method of stating the results of bacterial counts. In this method the bacterial counts are first divided into groups, as recommended by the American Public Ilealth Association. To each of these groups certain percentage values are given. The final expression is made as a single figure in terms of percentage.

The gromps and the percentage values recommended for each are as follows.

\begin{tabular}{|c|c|c|c|}
\hline Bacteria. & $\begin{array}{l}\text { Rating } \\
\text { figure. }\end{array}$ & Bactcria. & $\begin{array}{l}\text { Rating } \\
\text { figure. }\end{array}$ \\
\hline 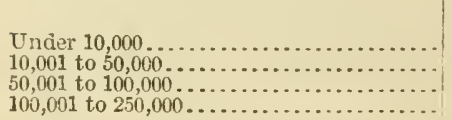 & $\begin{array}{r}\text { Per cent. } \\
100 \\
90 \\
75 \\
50\end{array}$ & $\begin{array}{l}250,001 \text { to } 500,000 \ldots \ldots \ldots \ldots \ldots \ldots \ldots \ldots \ldots \\
500,001 \text { to } 1,000,000 \ldots \ldots \ldots \ldots \\
\text { Over } 1,000,000 \ldots \ldots \ldots \ldots \ldots \ldots\end{array}$ & $\begin{array}{r}\text { Per cent. } \\
20 \\
10 \\
0\end{array}$ \\
\hline
\end{tabular}

In using the above table all of the bacterial counts are first divided into gronps, stating the number in each group. Each number is then 
multiplied by the percentage value of its group, as illustrated in the following table:

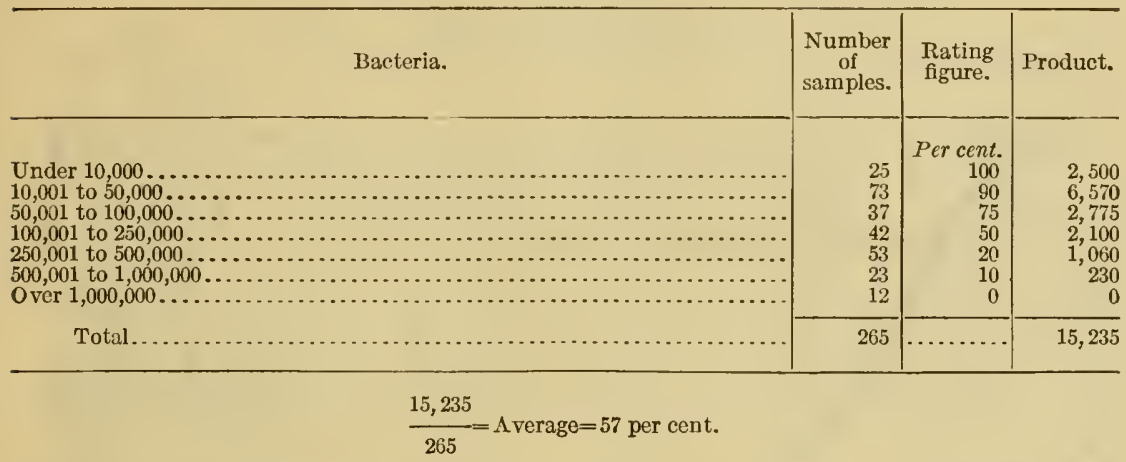

The final statement, which is the average of all percentages, is called by Levy the "bacterial index."

In reporting results of laboratory work under city conditions it is desirable that a more detailed statement be given than the single figures of "bacterial content" and "bacterial index," and it is therefore recommended that all tests made or at least all in each group be reported when possible as approved by the laboratory section of the American Public Health Association. 


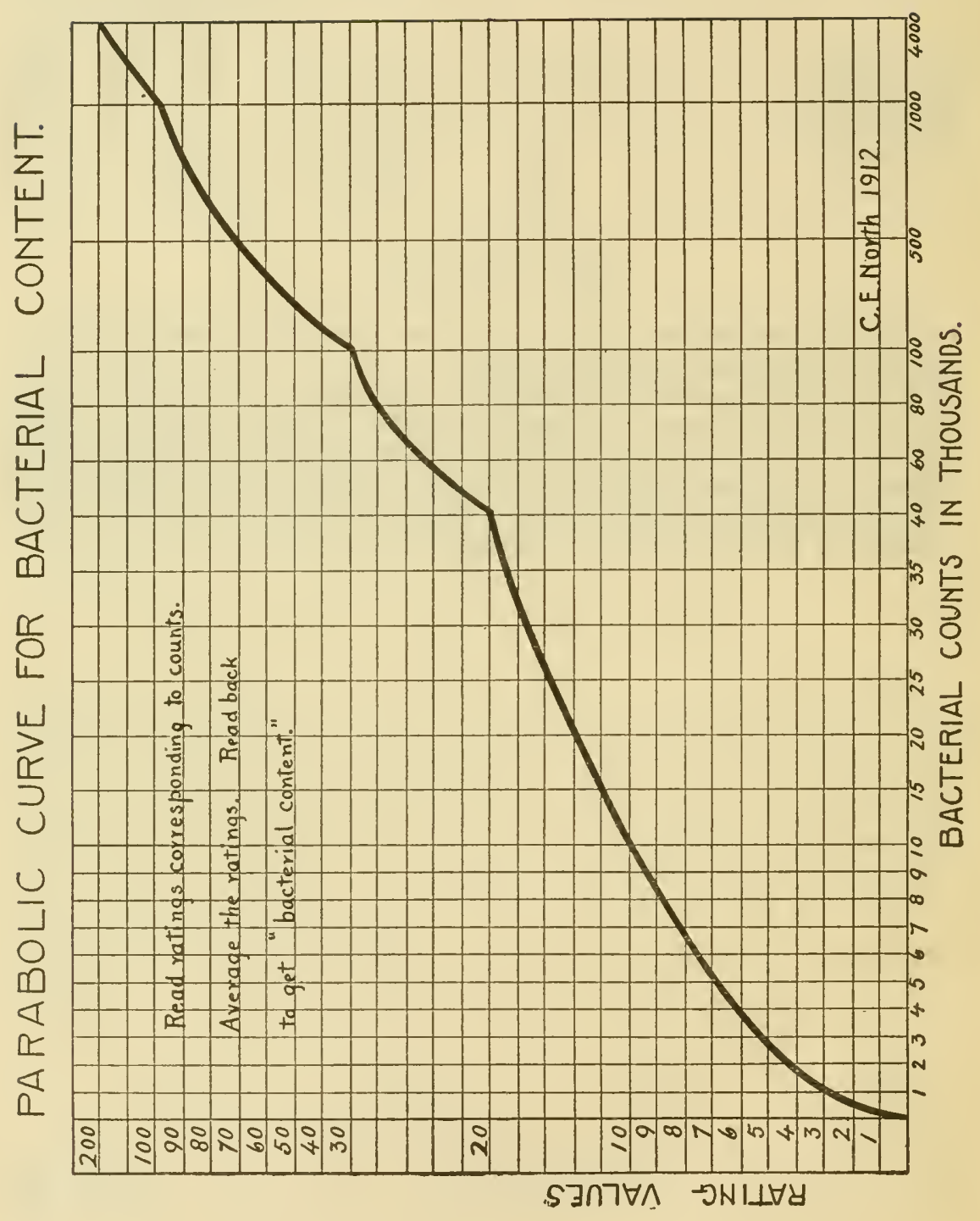


TIME AND TEMPERATURE FOR

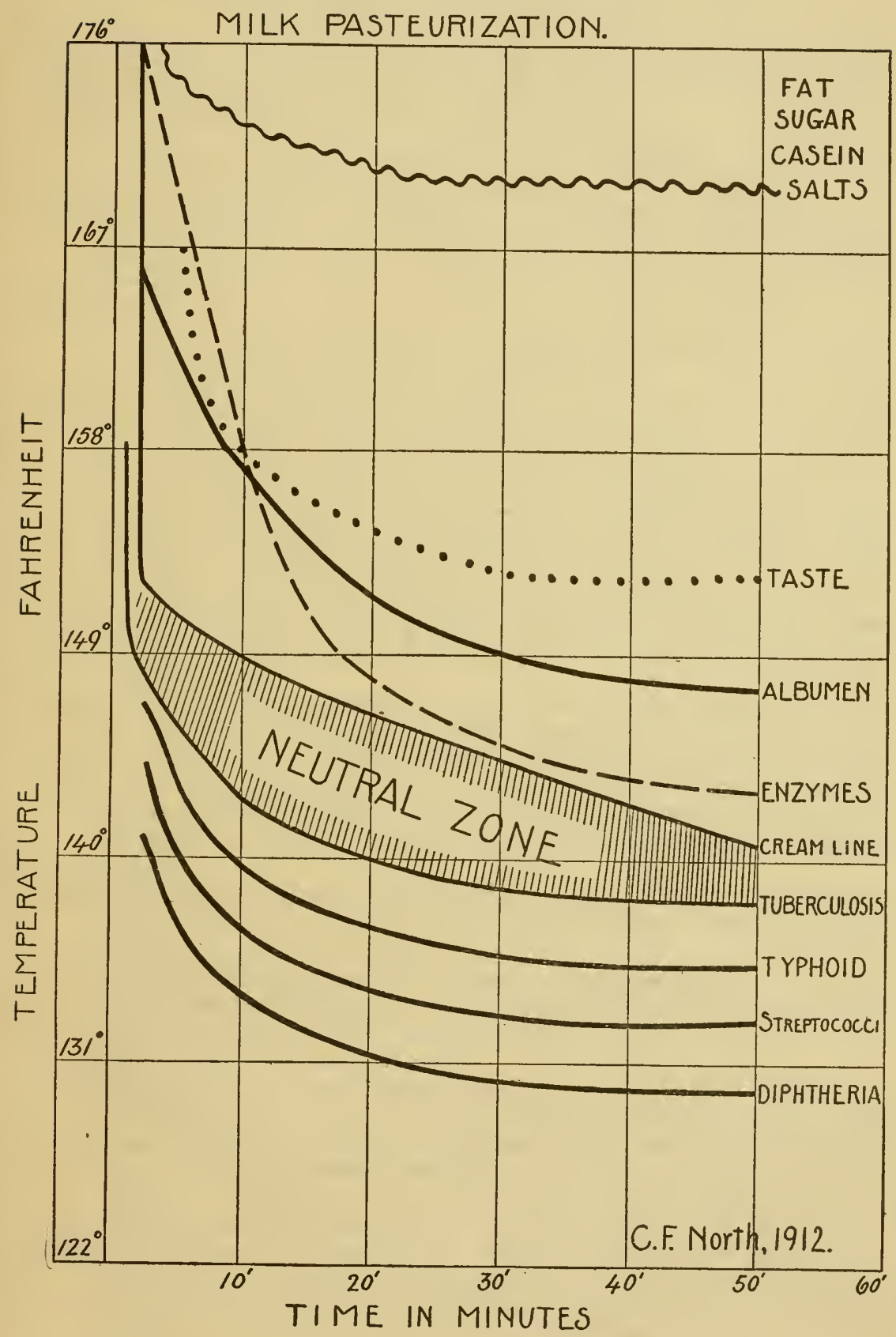





\section{REPRINTS FROM PUBLIC HEALTH REPORTS.}

[Those marked (*) are exhausted and no longer available for distribution. Those marked $(\hat{i})$ may be purchased irom the Superintendent of Documents at 5 cents a copy. Copies of the Public Health Reports containing these articles will be found in most public libraries, as will also the reprints themselves.]

†1. Precis upon the Diagnosis and Prevention of Smallpox. Reprint from P. H. R. No. 1, Voỉ. XlV, January 6, 1S99. 14 pages. Paper.

2. Plan of Organization for Suppression of Smallpox in Communities not provided with an Organized Board of Health. By C. P. Wertenbaker. Reprint from P. H. R. No. 42, Vol. XIV, October 20, 1S99. 23 pages. Paper.

*3. Mortality Statistics of 1,433 Cities and Towns of the United States for tlie Year Ended December 31, 1S95. Reprint from P. H. R. November 10, 1899. 24 pages. Paper. Out of print.

4. The Prophylaxis of I'lague by Preventive Inoculations. By Dr. A. Culmette, Director of the Pasteur Institute of Lille. Reprint from P. II. I. No. 34, Vol. NIV, August 24, 1900. 4 pages. Paper.

*5. The Intermational System of Nomenclature of Diseases and Causes of Death (Bertillon Classification, as adopted by the Eighth Internationa? Congress of Hygiene and Demography, Paris, Angust 18-21, 1900. Translated by H. D. Geddings). Reprint from P. H. R. No. 49, Yol. XV, December 7, 1900. 47 pages. Paper. Ont of print.

6. Yellow Fever Institute. Description of Organization. By Surgeon Gèneral Wyman. Reprint from P. H. R. No. 39, Vol. XVI, September 27, 1901. 7 pages. Paper.

*T. Mortality Statistics of 1,190 Cities and Tow us of the United States for the Year ended December 31, 1900. Reprint from P. H. R. No. 40, Vol. XVI, October 4, 1901. 23 pages. Puper. Out of print.

8. Plan for International Agreement of the American Republics for the Sanitation of Certain Seacoast Cities. By Surgeon General Walter Wyman. Iieprint from P. H. R. No. 41, Vol. XVI, October 11, 1901. 13 pages. Paper.

†9. The Prevention of the Spread of Scarlet Fever. By H. D. Geddings. Reprint from P. H. R. No. 3, Vol. XVII, January 17, 1902. \& pages. Paper.

10. Public Health and Marine-Hospital Service of the United States. An act to increase the efficiency and change the name of the United states Marine-Hospital Service. Reprint from P. H. R. No. 27, Vol. XVII, July 4, 1902. 4 pages. Paper.

*11. Plague Conference. Containing a copy of the address of the chairman and resolutions passed by a conference called in accordance with request from a number of state boards of health, and under antlority of section 7 , act of Congress approved July 1, 1902. to consider the plague situation. Reprint from P. II. R. No. 4, Vol. XVIIf, Jannary 23, $190 \%$. 9 pages. And February 6. 1903. 41 palges. Paper. Out of print.

12. Proplyylaxis against Yellow Fever. (Extract from a paper read by Dr. Jnan Guiteras before the First International Sanitary Conference of American Republics, held in Washington, D. C., December 2-5, 1902.) Reprint from P. H. R. No. 31, Vol. XVIII, July 31, 1903.6 pages. Paper. 
*13. Mortality Statistics of 1.563 Cities and Towns of the Uniter States for the Year ended December 31, 1902. Reprint from P. H. R. No. 32, Vol. AYIII, August T, 1903. 27 pages. Paper. Out of print.

*14. Precis on the Fly and Mosquito as Carriers of Disease. By H. D. Geddings. Reprint from P. H. R. No. 35, Vol XVIII, Angust 28, 1903. 10 pages. Paper. Out of print.

115. Precis on the Management of Outbreaks of Smallpox, Diphtheria, and Scarlet Fever. By H. D. Geddings. Reprint from I. H. R. No. 3s, Tol. xiIII, September 18, 1903. 1s pages. Paper.

i16. Conceruing the Geographic Distribution of the Yellow Fever Mosquito. By L. O. Howard. Reprint from P. H. R. No. 46, Vol. XVIII, November 1:3, 1903. Out of print. The above revised to September 10, 1905. 1.t pages. Paper.

*17. Second General International Sanitary Convention of the American Republics, concluded at Washington, D. C., October 14, 1905. Reprints from P. H. R. No. 5, Vol. XXII, February 1, 1907. 9 pages. Paper. Out of print.

*18. Brief History of Federal and State Action against Tuberculosis in the United States. Reprint from P. H. R. No. S, Vol. XXII, February 22, 1907. 18 pages. Paper. Out of print.

†19. The Fourth Lisease (Filatow-Dukes Disease). By J. W. Schereschewsky. Iieprint from P. H. I. No. 19, Vol. XXII, May 10, 1907. T pages. Paper.

*20. The Climate of New Mexico. Py Paul M. Carrington. Reprint from P. H. R. No. 28, Yol. XXII, July 12, 1907. 15 pages. Paper. Out of print.

21. Dengue Ferer, as Observed in Brownsville, Tex., August, 1907. By Joseph Goldberger and George W. McCoy. Reprint from P. H. R. No. 49, Vol. Xxil, December 6, 1907. 7 lages. 3 charts. Paper.

22. Ilague Investigations in India. Reprint from P. H. R. No. 50, Vol. XXI, December 13, 1907. 21 pages. Iaper.

23. The Prophylactic Value of Vaccination. By Henry S. Mathewson. Reprint from P. H. R. No. 5, Tol. XXII, Jaunary 31, 190S. 9 pages. I'aper. (Second edition.)

*24. IIow to Trap Rats. By W. C. Rucker. Reprint from P. H. R. No. 9, Vol. XxIII, February 28, 1908. \& pages. Paper. Out of print.

*25. Tiequest for Fleas for Identification and for Information Relative to Local Species of Fleas, Riats, and Mice. Reprint from P. H. Ir. No. 10, Tol. XXIII, March 6, 1908, 4 pages. Paper.

26. Measures to Prevent the Introduction and Spread of Plague. Reprint from P. II. R. No. 22, Vol. XXII, May 29, 1908. 9 pages. Paper.

†27. 'The Danger and Irevention of Tetanus from Fourth of July Wounds. Iir' John F. Anderson. Iieprint from P. H. Ii. No. 25, Vol. XXIII, June 19, 190S. 4 pages. Paper.

2. Irevention and Hestruction of Mosquitos. By Joseph Goldberger. Reprint from P. II. I. No. 29, Yol. XXIII, July 17, 190S. 11 pages. Iaper. (3il edition.)

†29. Notes on Rat Leprosy and the Fate of Human and Rat Lepra Bacilli in Flies. By Wm. I: Wherry. Reprint from P. II. R. No. 42, Vol. XxiII, October 16, 190s. s pages. Paper.

430. California Ground Squirrels. By C. Hart Merrium. Reprint from P. I. R. No. 52, Vol. XXII, December 25, 1908. S pages. Paper.

131. Experimental Investigation of Biting of Man by Fleas from Rats and Squirrels. By George W. McCoy and Maurice B. Mitzmain. Reprint from P. II. I. No. S, Vol. XXIV, February 19, 1909. 9 lages. Paper. 
†32. Campaign Against Ground Squirrels in Contra Costa County, California. By Rupert Blue. Reprint from P. H. R. No. 21. Vol. XXIT, May 21, 1009. 5 pages. Paper.

*33. Colored Antituberculosis League. Proposed Plan of Organization. By C. P. Wertenbaker. Reprint from P. H. R. No. 22, Vol. XXIV, May 2s, 1909. 9 pages. Paper. Out of print.

i34. The Prevalence of Pellagra in the United States. A Statistical and Geographical Note with Bibliography. By C. I. Lavinder. C. F. Williams, and J. W. Babcock. Reprint from P. H. R., No. 25, Vol. XxIV, June 1S, 1909. 6 pages. Paper.

†35. Epidemic of an Urticarioid Dermatitis Due to a Small Mite (Pediculoides ventricosus) in the Straw of Mattresses. By Joseph Goldberger and Jas F. Schamberg. Teprint from P. H. R., No. 28, Vol. XXIV, July ?, 1909. 6 pages. Paper.

†36. Hookworm Disease in its Relation to the Negro. By Ch. Wardell Stiles. Reprint from P. H. R., No. 31, Vol. XXIV, July 30, 1909. 10 pages. Paper.

37. The Treatment of Hookworm Disease. By Ch. Wardell Stiles. Reprint from P. H. R., No. 34, Vol. XXIV, August 20, 1909. 5 pages. Paper.

35. Plague Among Ground Squirrels in Cantra Costa County, California. By W. C. Rucker. Reprint from P. H. R.. No., 35, Vol, XXIV, Angust 27, 1909. 18 pages. Paper.

39. A Working Plan for Colored Antituberculosis Leagues. By C. P. Wertenbaker. Reprint from P. H. R., No. 36, Vol. XxIV, September 3, 1909. 12 pages. Paper.

†40. Notes on the Prognosis and Treatment of Pellagra. By C. H. Lavinder. Reprint from P. H. R., No. 3T, Vol. XXIV, September 10, 1909, 10 pages. Paper.

41. The Second International Conference on Leprosy, held in Bergen, Norway, Angust 16 to 19,1909 . By Donald II. Currie. Reprint from P. H. R., No. 3S, Vol. XXIV, September 17, 1909. 10 pages. Paper.

†42. Soil Pollution and its Relation to Hookworm Disease and Trphoid Fever. By Ch. Wardell Stiles. Reprint from P. H. R., Vol. XXIV, No. 40, October 1, 1909. 10 pages. 3 illustrations. Paper.

†43. The Prophylaxis of Pellagra. By C. H. Lavinder. Reprint from P. H. R., Vol. XXIV, No. 4t, October 29, 1909. 13 pages. Paper.

44. Summary of Transactions of the Public Health and Marine-Hospital Service, Fiscal Year 1909, and to Norember 1, 1909. Reprint from P. H. R., Vol. XXIV, No. 50. December 10, 1909. 16 pages. Paper.

45. The Evidence of Plague Infection Among Ground Squirrels. By George W. McCoy. Reprint from P. H. R., Vol. XXV, No. 2, January 14, 1910. $S$ pages. Paper.

46. What the Local Health Officer Can Do in the Prevention of Typhoid Ferer. By L. L. Lumsden. Reprint from P. II. R., Vol. XXY, No. 5, February 4, 1910. 14 pages. Paper. (Second edition.)

$\div 47$. The Straw Itch (Dermatitis Schambergi): A Disease New to American Physicians. By Joseph Goldberger. Reprint from P. H. R., Vol. XxV, No. 23, June 10, 1910. 8 pages. 2 illustrations. Paper.

48. What the Mayor and City Councii Can Do in the Prerention of Typhoid Fever. By L. L. Lumsden. Reprint from P. II. R., Vol. XxV, No. 24, June 17, 1910. 14 pages. Paper. (Second edition.) 
49. The Present Organization and Work for the Protection of Health in the United States. By Walter Wyman. Reprint from P. H. R., Vol. XXV, No. 38, September 23, 1910. 13 pages. Paper. (Second edition.)

*50. The History, Development, and Statistics of Milk Charities in the United States. By J. W. Ferr. Reprint from P. H. R., Vol. XXV, No. 39, September 30, 1910. 19 pages. Paper. Out of print.

†51. Pulmonary Hemorrhige in the Tuberculous at IIigh Altitude (6,200 feet); Report of 56 Deaths; Frequency of Associated Heart Disease. By F. C. Smith. Reprint from P. H. R., Vol. XXV, No. 40, October 7, 1910. 9 pages. Paper.

52. Bicteriological Procedure in Suspected Cholera, with Report of a Positive Case. By John I. Anderson and A. M. Stimson. Reprint from P. II. R., Vol. XXY, No. 42, October 21, 1910. 5 pages. Paper.

53. Cholera: Its Nature, Detection, and Prevention. By A. J. McLaughlin. Reprint from P. If. R., Vol. XXV, No. 44, November 2. 1910. 20 pages. Paper. ('Third edition.)

†54. Preliminary Note on a Simple and Inexpensive Apparatus for Use in Safe Disposal of Night Soil. By L. L. Lumsilen, Norman Roberts, and Ch. Wardell Stiles. Reprint from P. H. R., Vol. XXV, No. 45, November 11, 1910. 7 pages. 1 il. Paper.

755. The Field Investigation of Epidemic Poliomyelitis (What the Health Officer Can Do Toward Solving a National Problem). By W. H. Frost. Reprint from I'. II. R., Tol. XXY, No. 46, November 18, 1910. 19 pages. IReferences. I'aper.

†56. Report on an Outbreak of Typhoick Fever at Des Moines, Iowa. By L. L. Lumsden. Reprint from the P. H. R., Vol. XXVI, No. 4, January 2\%, 1911. 26 pages. 2 charts. 1 map. Paper.

757. Smallpox and Vaccination in the Philippine Islands. By Victor G. Heiser and Robert Oleson. Reprint from the P. H. R., Vol. XXVI, No. 10, March 10, 1911. 6 pages. Paper.

†58. The Typhoid Bacillus Car'ier: A Review. By R. M. Grimm. Reprint from the P. H. R., Vol. XXYI, No. 11, March 17, 1911. 17 pages. Paper.

59. Report on an Original Form of Sulphur Burner for Disinfection. By N. Roberts and 1: Alex. McDermott. Reprint from the P. I. R., Tol. XXVI, No. 13, March 31, 1911. 10 pages. 2 charts. 1 il. Paper.

†60. A Note on Smallpox and Vaccination in the Plilippine Islands. By Victor G. Heiser. Smallpox and Taccination in Cuba. By P. Villoldo. Reprint from the P. H. R., Vol. XXVT, No. 15, April 14, 1911. 7 pages. Paper.

61. Smallpox in the United States-Prevalence and Geographic Distribution durjng the Calendar Year 1909. By John W. Trask. Reprint from P. H. R., Tol. XXVI, No. 22, June 2, 1911. 9 pages. 1 table. 2 maps. Piper.

†62. Experimental Measles in the Monkey: A Supplemental Note. By John F. Anderson and Joseph Goldberger. Reprint from the P. H. R., Yol. XXYI, No. 24, Jnue 16, 1911. 11 pages. 2 charts. Paper.

6. Smallpox in the Enited States-Prevalence and Geographic Distribution during the Calendar Year 1910. By John W. Trask. Reprint from the P. II. R., Vol. XXYI, No. 25, June 23, 1911. 13 pages. 2 tables. 2 maps. Paper.

64. Data Regarding Operations of Infants' Milk Depots in the United States in 1910. Вy J. W. Kerr. Reprint from the P. II. R., Vol. XXVI, No. 33, August 1S, 1911. 20 pages. 8 tables. Paper. 
65. The Salient Epidemological Features of Pellagra. By C. H. Lavinder. Reprint from the P. H. R., Vol. XXVI, No. 39, September 29, 1911. 11 pages. Paper.

66. Antityphoid Vaccination. Extracts from the Report of the Commission appointed by the Academy of Medicine of Paris. Translation by Joseph W. Schereschewsky. Reprint fiom the P. H. R., Tol. XXVI, No. 40, October 6, 1911. 25 pages. Paper. (Second edition.)

67. Origin and Prevalence of Typhoid Fever in Fort Smith, Ark., and Measures Necessury for its Control. By IV. H. Frost. Reprint from the P. H. R., Vol. XXVI, No. 43 , October 27, 1911. 19 pages. Paper.

68. The Tarbagan (Arctomys bobac) and Plague. By Paul Preble. Reprint from P. H. R., Vol. XXVII, No. 2, January 12, 1912. 10 pages. Bibliography. Paper.

63. Epidemic Cerebrospinal Meningitis. A Review of its Etiology Transmission, and Specific Therapy, with Reference to Public Measures for its Control. By W. H. Frost. Reprint from P. H. R., Vol. XXVII, No. 4, January 26, 1912. 27 pages. Paper. (Second edition).

70. Municipal Ordinances, Rules, and Regulations Pertaining to Public Hygiene. Adopted from January 1, 1910, to June 30, 1911, by Cities of the United States Haring a Population of orer 25,000 in 1910. Prepared by direction of the Surgeon General. Reprint from Public Health Reports of March 24, 1911, to January 19, 1912, inclusive. Paper.

171. The Relation of So-called Brill's Disease to Typhus Ferer. An Experimental Demonstration of Their Identity. By John F. Anderson and Joseph Goldberger. Reprint from P. H. R., Vol XXVII, No. 5, February 2, 1912. 14 pages. 6 charts. Paper.

72. Vegetables as a Possible Factor in the Dissemination of Typhoid Ferer. By R. H. Creel. Reprint from P. H. R., Vol. XXVIT, No. 6, February 9, 1912. 9 pages. Paper. (Second edition.)

73. Typhus Fever in the United States. Differential Diagnosis from Typhoid Fever. Reprint from P. H. R., Vol. XXVII, No. 6, February 9, 1912. 5 pages. Paper.

74. The Transuission of Typhus Fever, with Especial Reference to Transmission by the Heacl Louse (Pediculosis capitis). By Joseph Goldberger and J. F. Anderson. Reprint from P. H. R., Vol. XXVII, No. 9, March 1, 1912. 13 pages. 6 charts. Paper.

75. The Bacteriological Diagnosis of Cholera. A Report Presented to the Permanent Committee of the International Office of Public Hygiene in the name of a Commission Composed of: Messrs. Ruffer, president; Cilmette, Gaffky, Gedllings, Murillo, Praum, and Pottevin, reporter. Translated from the French by Surg. H. D. Geddings, American Delegate on the Permanent Committee. Reprint from P. H. R., Vol. XXVII, No. 11, March 15, 1912. 30 pages. Piper.

76. The Necessity for Safe Water Supplies in the Control of Typhoid Fever. By A. J. Mclaughlin. Reprint from P. H. R., Vol. XXYII, No. 12, Mrirch 22, 1912. 13 pages. 5 tables. Paper. (Second edition.)

77. Sewage-Polluted Water Supplies in Relation to Infant Mortality. By Allan J. McLaughlin. Reprint from P. H. R., Vol. XXVII, No. 17, April 26, 1912. 36 pages. 24 charts. Paper.

7S. Report of the Commission on Milk Standards Appointed by the Yew York Milk Committee. Reprint from P. H. R., Vol. XXVII, No. 19, May 10, 1912. 30 pages. 2 charts. Paper. (Second edition.) 
79. Investigation of and Tick Eradication in Rocky Mountain Spotted Ferer. By Thomas B. Mcclintic. Reprint from P. H. R., Vol. XXVII, No. 20, May 17, 1912. 31 pages. Biblioglaphy. Paper.

So. Examination of Lxcreta for Typhoid Bacilli. By L. L. Lumsden and A. M. Stimson. Report of an Outbreak of Typhoid Ferer at Lincoln, Nebraska, in 1911. By L. L. Lumsden. Reprint from P. H. R., Vol. XXViI, No. 21, May 24, 1912. Paper.

81. Sanitary Adrice for Summer Tourists. Sanitary Advice for the Keeper's of Summer Resorts. By W. C. Rucker. Reprint from P. H. R., Vol. XXriI, No. 21, May 24, 1912. Paper.

S2. Studies on the Virus of Typhus. By John F. Anderson and Joseph Goldberger. Reprint from P. H. R., Vol. XXVII, No. 22, May 31, 1912. Paper.

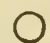





\section{LIBRARY OF CONGRESS}

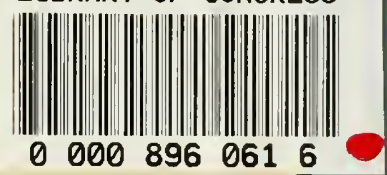

00008960616 



\section{LIBRARY OF CONGRESS}

||||||||||||||||||||||||||||||||||||||||||||||

\section{6}

Hollinger Corp. pH 8.5 